\title{
The Sociology of Gossip and Small Talk: A Metatheory
}

\author{
Ana Bilinović Rajačić ${ }^{1}$ - Aleksej Kišjuhas - Marko Škorić \\ Faculty of Philosophy, University of Novi Sad, Novi Sad
}

The Sociology of Gossip and Small Talk: A Metatheory. The present paper outlines a metatheory of gossip and small talk. While studies in the domain of the sociology of gossip are relatively sporadic, nonsystematic, and sparse, we find it possible to identify three key perspectives from which social scientists usually consider gossip. These three perspectives closely correspond to George Ritzer's metatheory, as well as his differentiation between the social facts paradigm, the social definition paradigm, and the social behavior paradigm in sociology. Hence, in this paper, we also offer a brief overview of sociological research on the phenomenon of gossip, as well as studies conducted with the aim of answering the question of what people gossip about. Further, we thoroughly analyze the three abovementioned paradigms, which are here conceptualized as separate theoretical perspectives in the sociology of gossip. Concordantly, we argue the existence of functionalist, dramaturgical, and social exchange perspectives in the context of theoretical and empirical research on gossip in the field of sociology as well as other social sciences. Finally, we claim that gossip is one of the essential characteristics of social life and, as such, plays a crucial role in the most important social processes, such as the maintenance of group and social cohesion, the transfer of cultural values, sociocultural learning, the establishment of social control, the process of gaining social reputation and status, social exchange of information, and others, which is why we believe that gossip merits a more central position in sociological inquiries. Sociológia 2020, Vol. 52 (No. 6: 559-577)

https://doi.org/10.31577/sociologia.2020.52.6.23

Key words: Gossip; small talk; metatheory; functionalist perspective; dramaturgical perspective; social exchange perspective.

In its essence, gossip is a social activity and it exists in all known societies (Bloom 2004; Dunbar 2004). In the most general and value-neutral sense, it can be defined as "a general interest in the doings, the virtues and vices of others" (Gluckman 1963: 308). Gossiping is often equated to "idle talk" or "small talk" about others, everyday phenomena, and life in general. While gossip is a decidedly ordinary social activity, defining, operationalizing, and measuring it represent a complex enterprise in the research context (Foster 2004). Namely, and according to the popular view, gossip is not a particularly useful activity and it is rarely seen as a system of transmitting relevant information. One of the results of such unfavorable attitude towards this phenomenon is the fact that gossip is not a prominent topic in mainstream sociological research. Furthermore, it is often treated as a negative evaluative speech act, "evil tongue", disrespectful, distasteful, and nearly shameful activity (Wert Salovay 2004), as well as an act that invades other people's privacy and is used to spread misinformation (Foster 2004). In this context, certain theoreticians

\footnotetext{
1 Address: Dr Ana Bilinović Rajačić; Prof. Dr Aleksej Kišjuhas; Prof. Dr Marko Škorić, University of Novi Sad, Faculty of Philosophy, Dr Zorana Đinđića 1, Novi Sad 21000, Srbsko. E-mail: ana.bilinovic@ff.uns.ac.rs; aleksej.kisjuhas@ff.uns.ac.rs; mskoric@ff.uns.ac.rs
}

Sociológia 52, 2020, No. 6 
highlight that "the most negative image of gossip reflects a situation in which destructive rumors that have no basis in fact are spread" (Tannen 1991: 50).

It is necessary to draw attention to one specific view of the development and function of language that has direct implications for the understanding (and the status) of gossip. It can be said that language developed in order to enable our ancestors to exchange information about the physical world they lived in. Dunbar (Dunbar 2004) claims that this (common) perception of the function of language led to the trivialization of all other uses of language that came to be viewed as motivated by idleness. For these reasons, gossip has gained an undeserved bad reputation and it has often been described as a sheer waste of time.

Nonetheless, gossip represents a legitimate research problem as it is an important form of social knowledge and social learning, a means of defining social norms, a mechanism of social control, a means of enhancing or diminishing social prestige, a prominent element of nearly every social interaction and social exchange, and so forth, all of which are phenomena that are of key importance for social life in general, as well as for sociology as a science. On top of that, gossip helps maintain and strengthen social bonds, that is, social solidarity in the Durkheimian sense (Durkheim 1912/1915). Having this in mind, it is surprising that studies in the domain of the sociology of gossip are relatively sporadic, unsystematic, and sparse.

On the other hand, even though the sociology of gossip is not explicitly institutionalized, gossip has been the subject of certain sociological studies concerning language and speech. In this context, a significant although equally marginalized aspect of research on gossip has been the study of the content of gossip, that is, what people gossip about. Furthermore, social anthropology, social and evolutionary psychology, and evolutionary biology can provide (and have provided) important incentives for studying gossip from the sociological perspective. In this paper, one of our aims is to highlight the contributions such studies have made to the formulation of the paradigms of the sociology of gossip.

Small talk is often perceived as a superficial form of communication riddled with platitudes. In other words, the term "small talk" represents an antithesis of the allegedly "real", "full", "serious" or "useful" conversation (Coupland 2003: 2). Still, some papers have drawn attention to the positive, prosocial functions of small talk (see Baumeister et al. 2004; Foster 2004; Dunbar 2004; Tanner 1991) and pointed out that (similar to gossip) it is a phenomenon that contributes to social cohesion and aids the structuring of social interactions. In this sense, the significance of gossip and small talk in social life seems indisputable, which indicates the need for (more) theoretical and empirical studies focusing on these phenomena. 


\section{Research on gossip and (small) talk}

Research on gossip is rooted in numerous disciplines, primarily social anthropology and ethnography (see Foster 2004), and it relies on various distinct research methods. Within the abovementioned disciplines, research on gossip has mostly been conducted through fieldwork (participant observation research strategy), as well as video and audio recording of conversations. Furthermore, researchers have also "eavesdropped" on participants in public places in order to avoid disrupting the spontaneous aspects of interaction during gossip sessions (e.g. Dunbar et al. 1997). Certain psychometric studies strived to collect information on personalities of those who gossip and those who are the subjects of gossip (Jaeger et al. 1994). In the context of research on gossip, social network analyses are particularly fruitful, as the position of an individual within the network and the individual's network density can be important predictors of gossip spreading (e.g. Lind et al. 2007).

In the context of natural, spontaneous conversations among adolescents, it has been observed that the key elements based on which gossip is recognized are the identification and evaluation of its subject (Eder - Enke 1991; Fine 1986). What is characteristic about gossip is that the subject of evaluation is not present. After the subject has been identified and evaluated, various reactions and responses may ensue, like explanations, expansions on the evaluation, support, overemphasized affect, and challenges (Eder - Enke 1991: 497). We can conclude that in these studies, gossip episodes were usually initiated by adolescents of high or middle status within their peer group or school as a whole, that the evaluation was only challenged by adolescents of equal or higher status in comparison to the person who's evaluation is being challenged, and that support was provided by adolescents of all statuses (Eder - Enke 1991: 504-505). Similarly, Fine (Fine 1986) draws attention to the fact that female adolescents use gossip in order to clarify the norms that are based on the collective evaluation of the situation.

One of the most complex gossip-related research questions is that of determining the exact amount of time people spend gossiping. Emler (Emler 1994) provides a partial answer to this research question. He sampled conversation topics in different situations and concluded that about $70 \%$ of conversation time was dedicated to what he defined as "gossip". Thus, gossip is a highly common speech act in informal groups, which is why it is hard to understand why sociologists' attempts to examine its nature and structure are so rare. The same goes for research on the content of gossip, that is, what exactly people gossip about. 


\section{What do humans (small) talk about?}

An essential feature of language is that it enables us to exchange information and follow the development of events within our social networks, though it can also be used to maintain relationships within those networks (Dunbar 2004). One could claim that gossip has these same features and functions. In this context, Dunbar states: "in a nutshell, I am suggesting that language evolved to allow us to gossip" (Dunbar 1996: 79). Still, the number of studies that focus on the content of conversations (and gossip) in relaxed or informal social surroundings is surprisingly small.

Certain early researchers wrote about the significant influence of the sex of participants on the selection of conversation topics. The first to systematically analyze gender differences in the context of conversation topics was Henry Moore (Moore 1922), who claimed that these differences persist through time. $\mathrm{He}$ interpreted them as (stereotypical) manifestations of male and female "natures". Findings of one of the early studies on this subject (Landis - Burtt 1924) showed that male-to-male conversations usually focused on job-related topics, which is in line with Moore's findings, while sport/leisure and behavior of other men occupied the second and third position on the list of favorite topics. In contrast, conversations among women mostly focused on men, which is also in line with Moore's findings, while the second and third favorite topics were clothes and other women's behavior. In mixed, male-to-female dyads, the patterns were quite similar, although in such scenarios, men tended to speak more about themselves than other men.

Later studies (Haas 1979; Kipers 1987) suggest that gender differences in the context of conversation topic selection have changed since the time when Moore wrote about them, even though there is no systematic research on these trends. Bischoping (1993: 2) suggested that the "most striking developments in this area since 1992 are found in the discourse about gender and conversation, rather than in conversations themselves". A recent research conducted by Eckhaus and Ben-Hador (2017), which focused on gender-based differences in gossiping habits, established that in the quantitative sense, men and women spend approximately the same amount of time gossiping, as well as that women's gossip is more positive than men's.

Dunbar and his colleagues conducted numerous observational studies focusing on the content of conversations in public places. They noted topics in free-running conversations in 30-second intervals, using broadly defined categories (social topics, sport, music and culture, technical topics) (Dunbar et al. 1997). The results were highly consistent: social topics (broadly defined here as "gossip" and/or "small talk") accounted for approximately $65 \%$ of speaking time, with small variations due to age and gender (Dunbar et al. 1997: 
105). All other topics combined accounted for only one third of speaking time, which is consistent with the abovementioned findings reported by Emler (Emler 1994).

\section{Metatheory of the sociology of gossip}

As suggested previously, gossip is a human cultural universal (Brown 1991), it occurs relatively early in child development, and it performs a highly important social function (Bloom 2004). Sociologists, among other, ask questions related to the social function of gossip, its ritual and dramaturgical characteristics, its role in social exchange, and the like. Gossip can be associated with the preservation of group unity, collective values, and group morals. It is a particularly important phenomenon in the context of maintaining the dramaturgical aspects of human interaction. Furthermore, gossip is an important aspect of the exchange process of socially relevant information. For all these reasons, it possesses certain characteristics that (also) attract the theoretical attention of sociologists and social scientists, even though a relatively small amount of attention has been dedicated to the analysis of the very theoretical perspectives from which it can be considered.

This is a problem that falls into the domain of metatheory. In the sociological context, metatheory can be defined as the study of those structures that are at the core of the sociological theory. Ritzer (1975/1980, 1988) differentiates between three paradigms or basic theoretical perspectives in sociology: the social facts paradigm, the social definition paradigm, and the social behavior paradigm. It can be said that these paradigms correspond to the key perspectives in theorizing gossip: the functionalist, dramaturgical, and social exchange perspectives (see also Ritzer 1981; 1988; 1990).

Apart from Ritzer and his concept of paradigm, other metatheoretical approaches in sociology take a small group of theoreticians ("school") as the unit of analysis or they analyze wider groups of theoreticians ("school of thought", "theoretical perspective", etc.) (e.g. Martindale 1960; Eisenstadt 1981; Turner 1998).

The proliferation of the term "paradigm" in sociology and applied to sociology is both visible and empirically verifiable (Perry 1977), even though this term is often used in multiple meanings and its (mis)use in sociology is frequently the subject of criticism (e.g. Merton 1968: 72; Urry 1973). Also empirically proven is the proliferation of metatheoretical studies in sociology (Fuhrman - Snizek 1990), that is, the nature of sociology as a multiparadimatic science (Lodahl - Gordon 1972). There is no universal consensus on the number of paradigms in sociology, with the number usually ranging from two to eight (Eckberg - Hill 1979). 
Due to the microsociological aspects of gossip, we use Ritzer's metatheory as the framework for this paper. Ritzer defines a sociological paradigm as "the broadest unit of consensus within a science" that serves to "differentiate one scientific community from another" (Ritzer 1975/1980: 7). His concept of social paradigm implies: one or more sociological theories, an image of the subject matter, typical methods and instruments, and specific common exemplars. Therefore, in the social facts paradigm, the image of the subject matter is social facts and functions (Durkheim 1895/1982), that is, social institutions and social cohesion. Sociological theories that belong to this paradigm include structural functionalism and conflict theories, the methods of this paradigm are usually historically comparative, and the typical instrument is the questionnaire.

In the social definition paradigm, Weber's theory of social action is an exemplar (Weber 1921/1978), the definition of the situation is the shared image of the subject matter (Thomas - Thomas 1928), and observation is its distinctive methodology. Sociological theories encompassed by this paradigm include action theory, symbolic interactionism, phenomenological sociology, ethnomethodology, with conversation analysis in particular, and others ${ }^{2}$.

Finally, in the social behavior paradigm, a common example is Skinner's behaviorism, the image of the subject matter is human automatic behavior and rewards and punishments that influence behavior, and its distinctive method is experiment. A theoretical orientation characteristic of this paradigm includes theories of social exchange and rational choice (Homans 1961/1974; Blau 1964/1986). Ritzer's model has been empirically tested through an analysis of 24 typical sociological studies. The theoretical groupings he suggested have been verified (Freidheim 1979), while receiving certain criticism (Harper et al. 1980; see also Ritzer 1981; Hill - Eckberg 1981). What follows is a detailed critical analysis of theories and research on gossip and small talk in the context of each of these three metatheoretical paradigms.

\section{Gossip in functionalist theorizing}

Functionalism in sociology can be traced from the organismic analogies of Comte (1830-42/1896) and Spencer (e.g. Spencer 1892), through Durkheim $(1912 / 1915)$ and the anthropological traditions (Radcliffe-Brown 1952, Malinowski 1960), to the works of Parsons (Parsons 1951), Merton (1968),

\footnotetext{
2 Conversation analysis, like ethnomethodology, has roots in phenomenology, whose primary goal is to explain the way social order is produced and enacted (Drew - Heritage 2006). Conversational analysis researchers focus on naturalistic conversation and procedures that allow actors to understand the reality, with constant awareness of the context that emerges from the interaction (e.g. Goodwin - Heritage 1990; Hutchby 1998). That is why one of its greatest flaws is that it usually does not take into consideration the extrainteractional context, which includes ideology, history, power relations, and interactions of the local and the global, although there are certain exceptions, even in research on gossip, where conversation analysis strives to incorporate all these factors (Besnier 2009).
} 
Luhmann (1984/1995), and Alexander (e.g. Alexander - Colomy 1985). In its essence, this theoretical tradition emphasizes and analyzes the contributions that various sociocultural practices make to the preservation of functional unity and solidarity, that is, the functioning of the social system. For example, functionalists or "social factists" ask questions such as: Which mechanisms order interrelated actions in physical space? or What kinds of symbolic contents are used by the social system to organize social actions? This tradition sees gossip and small talk as social facts that (also) have positive qualities that are often neglected - they preserve the unity, morals, and values of social groups (Gluckman 1963). Gossip unifies social groups and sometimes, this unification is directed against another group (see e.g. Coser 1956). On the other hand, when a group is no longer able to successfully achieve its goals or maintain the equilibrium, then gossip (or scandal) only accelerates the process of its disintegration.

Literature on social functions of gossip focuses on its four crucial social functions (see Stirling 1956; Foster 2004). These functions include: information, entertainment, friendship (or intimacy), and influence/social control. In addition, gossip plays multiple roles, including the transfer of social information about people, communication of general social rules, indirect aggression, social comparison, and the establishment and reinforcement of sanctions (Bloom 2004: 139). In a certain sense, gossip also reduces complexity and maintains boundaries in a given social system (see also Luhmann 1982/1986).

From the functionalist perspective, gossip represents an important and efficient means of transferring information concerning rules, norms, and other guidelines for living in a certain culture. Thus, it can perform the function of cultural learning (see Baumeister et al. 2004), even though individuals can be interested in gossiping without being aware of any desire to promote cultural learning. In this context, gossip stories about norm violations can be more informative than stories about activities that are in accordance with the norms. Namely, negative gossip can be more useful than its positive counterpart, since it is far more important and adaptive to learn about the natural and social dangers, due to their potential severity and harm for the individual.

The entertainment function of gossip can be easily observed in situations in which actors in conversation "kill time" by gossiping. In this context, it is emphasized that "gossip undeniably gives thrill and excitement" (Chua - de la Cerna Uy 2014: 66). The friendship function can be observed in the exchange of information through gossip that brings together the group members (or friends) and marks the difference between insiders and outsiders (Merton 1972). On a related note, certain theorists claim that people who do not gossip (or do not respond to the invitation to gossip with at least a small dose of 
interest) can easily be marginalized in their immediate social environments (e.g. Eggins - Slade 1997).

Finally, gossip also performs the social control function, in the sense of controlling so-called free riders. Certain experiments conducted on small groups (Orstrom et al. 1994) showed that even the opportunity to comment on the behavior of free riders can produce a significant effect on the willingness of these individuals to break ranks on implicit or explicit social contracts. That is, due to sensitivity to the opinions of others, humans tend to change their own behavior in order to avoid behaviors that others may perceive as negative. In that sense, gossip represents an informal device for controlling social cheaters (Dunbar 2004).

\section{Gossip in dramaturgical theorizing}

The dramaturgical perspective originates from the work of Erving Goffman (Goffman 1959), but its roots can be traced back to the philosophy of pragmatism and Mead and Cooley's (Rock 1979) analysis of the self. It is also important to mention European contributions and interaction analyses conducted by Simmel (1950) and Durkheim (1912/1915). Other significant works include the analysis of the nature of social (symbolic) interactions and role-taking conducted by Blumer (1969) and Kuhn (1964), where humans interpret each other's gestures (see also Thomas - Thomas 1928). It is also important to mention the analysis of self and identity formation (Stryker Burke 2000), as well as role theories which claim that actors in a given society follow written scripts like actors on the stage (Turner 2002). For the authors like Goffman and other "social definitionists", social reputation, presentation of desirable information, and the maintenance of the definition of the situation are crucial mechanisms concerning sociality.

Therefore, scholars and researchers who consider gossip from the dramaturgical perspective (or that of the social definition paradigm) usually emphasize the positive and negative effects of gossip on one's social reputation, that is, they emphasize the role of gossip in the context of the definition of the situation. In other words, they claim that gossip can primarily help build a good reputation, as well as a bad one, which indicates that it is a phenomenon and practice that has "strong manipulative potential" (Sommerfeld et al. 2007). According to anthropological and sociological research, some of the most common gossip topics are personal qualities, inconsistencies in behavior, character flaws, bad manners, socially unacceptable types of behavior, improprieties, and oversights (see Bergmann 1993: 15). Most of the abovementioned phenomena are at the very core of theoretical interests of Erving Goffman (Goffman 1959) and the dramaturgical 
theorizing in sociology in general. Namely, Goffman believes that individuals are actors who manage their impressions and "put on" a performance, which may at times be cynical, deceptive, and misleading.

The common core of the listed "dramaturgical" dimensions of gossip is their focus on the negative aspects of the actor's behavior, as well as the focus on behavior evaluation. Each of these topics is based on a unique evaluation or comparison between the individual who is the subject of gossip and certain social reference points, such as social norms or personal views and behavior (Wert - Salovey 2004: 123). What follows is that the dramaturgical perspective does not only insist on the deceptive performance of the actors, but also on the comparative value of the (demonstrated) adherence to normative rules and the maintenance of interaction order.

The theory of social comparison was formulated by Leon Festinger (Festinger 1954), who believed that humans have the basic need to evaluate their opinions and abilities in relation to real, objective criteria, that is, through "objective reality tests". However, in the absence of these objective reality tests, individuals need to rely on one another in order to obtain information on the validity and adequacy of their attitudes and behaviors.

There are several types of comparisons that are conducted through gossiping: 1) comparison with similar others; 2) comparison with those who are less able, powerful or fortunate (downward social comparison); 3) comparison with those who are more able, powerful or fortunate (upward social comparison); 4) comparison of in-group with out-group; 5) comparison with imaginary or socially constructed entities (constructed social comparison); and 6) comparison with others for the purpose of understanding one's emotional states (emotional comparison) (Wert - Salovey 2004: 124).

When individuals are interested in comparison as a means of obtaining accurate information about themselves, they tend to choose individuals who are similar to them. This is why Collins thoroughly analyzed (and predicted) the content of conversations between individuals, as well as the actors' affinity for similar others and common conversation topics (Collins 1975). By listening to gossip, a person can learn valuable lessons on how one should (not) behave. At the same time, people are highly prone to comparison with others whom they consider to be less able in a certain domain, in which they feel threatened at the given moment (Beauregard - Dunning 1998). Gossip can also be an exceptionally suitable means of collecting information on individuals who are more able or more powerful. This suitability stems from the fact that gossip allows for the collection of information in an indirect and private manner, by which individuals avoid the potential embarrassment they could experience during a face-to-face comparison (Wert - Salovey 2004: 126; see also Goffman 1956). 
Furthermore, gossip is often used as a means of in-group and out-group, usversus-them comparison (Chua - de la Cerna Uy 2014: 65), where one can observe a strong preference towards a positive attitude towards "us", that is, ingroup (Turner 1975). People also spread gossip about the members of their own group, in order to obtain information with which they could compare their own attitudes and shape (group) norms. Group norms are particularly reinforced through gossip in situations in which there is an observed threat to the group's identity (Gluckman 1963; see also Stryker - Burke 2000). When it comes to constructed social comparison, the subject of gossip is often compared and evaluated in relation to an imagined set of qualities or an imaginary entity that embodies the norms and values of the group.

The social comparison theory was expanded with the introduction of the emotion dimension by Schachter (Schachter 1959), who believed that people turn to one another in a threatening situation. Under such circumstances, humans tend to communicate with others who are similarly threatened. A consequence of such behavior is the gossip itself.

Thus, social comparisons have certain emotional consequences. In this context, it is interesting to draw attention to the feelings of pride, contempt, envy, and jealousy (Wert - Salovey 2004). When it comes to pride, this emotion grows in the presence of an audience. Consequently, gossip can be a means by which an individual who spreads it is given the opportunity to assert his or her superiority in front of others. Contempt is an emotion that can easily motivate gossiping. Likewise, envy serves as motivation for gossip and, apart from recognizing the advantages of someone else, it also requires the recognition of one's own unfavorable position. Finally, the feeling of jealousy may be the result of feeling threatened or the perception that the compared individual is a rival in the dramaturgical context of the interaction (for the sociology of jealousy, see Clanton 1996). Envy and jealousy are preferably expressed indirectly, which is why gossip represents a particularly suitable means for their expression.

Similar to gossip, small talk has a distinguished role in dramaturgical theorizing. Goffman also wrote about "face-work" (Goffman 1955), shame and embarrassment (Goffman 1956; see also Scheff 2000), and "supportive interchanges" and "remedial interchanges" in conversations and interactions (Goffman 1971). Namely, from the dramaturgical perspective, it is essential to leave an impression of competence during interaction, but that is often not enough. Our social success (e.g. at work) is greatly determined by our ability to engage in small talk, since small talk plays an important role in the maintenance of a relatively coherent work environment (Coupland 2003). Furthermore, the value and social significance of small talk are extremely "contextualized" (Coupland 2003: 5). Orientations and frameworks of the 
speakers as well as the starting points change and reflect the changes in priorities that arise during a conversation (see also Goffman 1974).

Simply put, from the dramaturgical perspective, gossip is a strategy individuals use to manage the impressions, to improve their reputation, and further their interests at the expense of others (McAndrew 2008). Apart from mere evaluation, gossip frequently includes opinions or emotions related to certain information. We rarely exchange information without expressing our feelings and attitudes, at least implicitly. This is accomplished through intonation, facial expressions, stance, posture, gestures, and so forth, all of which are key dimensions of theoretical research from the dramaturgical perspective or within the social definition paradigm.

\section{Gossip in social exchange theorizing}

Theories of social exchange or the social behavior paradigm insist on the significance of market forces and self-interested behavior of actors in societies, which can be traced from Adam Smith (1759/2002), through the exchange analysis in anthropology (Mauss 1925/1966), to Homans (1961/1974) and Blau (1964/1986). It is also important to mention Emerson and Cook's analysis of exchange networks, social circles in the context of intercategory and intracategory exchanges, and commitment processes in social networks (e.g. Cook - Emerson 1978; Yamagishi et al. 1998), as well as authors such as Coleman (1990) and Molm (1997). These theorists viewed social organization as closely related to the elementary processes of everyday exchanges, claiming that it is how patterns of social behavior, social power, and social structure are built (see also Emerson 1976).

As individuals, we are "programmed" by natural selection to be social animals and to participate in exchange interactions with members of our species. Throughout human evolution, information has been one of the most common objects of exchange (Wright 1994). In the environment of evolutionary adaptedness (Barkow et al. 1992), in which human mental evolution took place, information about enemies, predators, food, water, and the like had exceptional, life-saving value. Of considerable worth was also information concerning the social maneuvering of life resources - who is sleeping with whom, who is angry with whom, who cheated on whom, and so forth (Boyer 2001). At the same time, during information exchange in social interaction, it is possible to discover differences in status as well as intragroup and intergroup differences (see also Collins 1975).

Hence, from the social exchange perspective, gossip is regarded as an efficient and sometimes exclusive means of collecting, exchanging, and spreading information through social interaction. This information can represent a certain benefit or reward for the actors, in accordance with the 
postulates of the social behavior paradigm. Particular importance is attributed to information that people do (not) want to be spread which includes topics of adaptive value, such as status, resources, and sex (Boyer 2001: 122). If gossip was not to include these topics, it would lose its appeal.

Gossip is often characterized as a unique currency, which is exchanged like any other and whose value is determined by the recipient on the basis of its timeliness, usefulness, and in particular, rarity. Certain theorists (Rosnow Fine 1976) found that both gossip and the traditional patterns of economic exchange rest on the transaction pattern. Having this economic analogy in mind, gossiping could be defined as "an instrumental transaction in which A and B trade small talk about $\mathrm{C}$ for something in return - more gossip, status, fun, money, social control, or any material or psychological stimulus ..." (Rosnow 1977: 158).

The social exchange perspective also points to the fact that during hard and uncertain times, in the context of the abovementioned emotional comparison (Wert - Salovey 2004), gossip can serve as a source of information. This has been confirmed through research on a closely related phenomenon - spreading rumors. When faced with an unfavorable situation, people experience anxiety, which propels them to spread rumors, which in turn helps relieve emotional tension (Rosnow 1991). Therefore, anxiety is one of the causes of human tendency towards gossiping and individuals with self-identified high levels of anxiety regularly participate in gossiping.

Furthermore, gossip motivated by anxiety and uncertainty is particularly common in social relations in which one individual, normally dependent, has little information on the character and intentions of the person upon whom he or she depends (Wert - Salovey 2004: 132; Emerson 1962 also wrote about power-dependence relations from the social exchange perspective). Under such circumstances, negative gossip about a person of power can be of great use as it may help foresee future threats. Thus, any person of power can expect to be a frequent subject of gossip.

Finally, Michael Hechter (1987) studied how rational actors remain devoted to normative group structures via mechanisms of dependence, monitoring, and sanctioning. When the monitoring and/or sanctioning capacity of a group is low, it becomes difficult to ensure compliance to group norms. As emphasized previously, a key vehicle of these mechanisms is gossip itself, since it provides the necessary means to monitor and sanction nonconformity. In this manner, gossip ensures solidarity and group cohesion via social exchange of information. 


\section{Conclusion}

As early as in the 1960s, Max Gluckman (1963) claimed that gossip defined social groups: if no one told us a gossip, this meant that we were outsiders. At the same time, one of the key functions of gossip is sociocultural learning. It is also used as a means of social control, i.e. a sanction that forces individuals to adhere to the social norms more strictly than they otherwise would. Reputation is also dramaturgically determined via gossip, while casual conversations and small talk about others affect the relative standing and acceptability of an individual as a mate or a partner in social exchanges. Thus, we believe that it is possible to outline a metatheory or three distinct paradigms in the sociology of gossip (Ritzer 1975/1980), in spite of its marginalized position in sociological inquiries.

Finally, one could ask the following question: What is the significance of a metatheory, that is, how could it contribute to the sociological theory (of gossip and small talk)? Certain authors believe that sociological metatheories are merely descriptive or philosophical activities void of any scientific or explanatory pretentions and results (Collins 1986; see also Turner 1990). However, we believe that metatheoretization is not an end in itself, primarily because it indicates the adequate direction for ensuring the growth, progress, cumulativeness or even integration of sociological knowledge (Wagner Berger 1985; see also Seidman 1986; Wagner - Berger 1986). In the same vein, an overly narrow focus on the functions of gossip in the context of preserving group unity and its dramaturgical and interactional aspects, that is, gossip as information in the context of social exchange, makes any monoparadigmatic perspective relatively limited.

In this sense, metatheories do contribute to the potential synthesis of theoretical knowledge in the domain of sociology, which often seems exceedingly complex in its heterogeneity and diversity. Hence, sociological metatheory typically subsumes, defines and interlinks examples, theories, and methods of sociological research. This is to say that concrete sociological theories are placed within the frameworks of broader paradigms, while methateory's primary goals include their explication and relatively precise demarcation. This is exactly what we attempted to do in this paper, concerning the sporadic and sparse theoretical sociology of gossip, mainly by systematically and critically analyzing individual theories on gossip and synthesizing them into a broader (meta)theoretical framework.

Ana Bilinović Rajačić is assistant professor of sociology at the University of Novi Sad, Serbia. Her main interests are anthropological theories, sociology of science, sociology of family, family policy, reproductive tehnologies, politics of 
reproduction and social pathology. She authored more than 40 scientific papers and participated in 8 scientific research projects.

Aleksej Kišjuhas is associate professor of sociology at the University of Novi Sad, Serbia. His main interests are sociological theories, sociology of emotions and the history of sociological thought. He coauthored the book Evolution and Natural Selection from Anaximander to Darwin (2012, in Serbian, with M. Škorić) and book Revolutions and Societies: An Introduction to the Theoretical Sociology of Revolutions (2018, in Serbian, with M. Škorić). He authored numerous scientific papers.

Marko Škorić is associate professor of sociology at the University of Novi Sad, Serbia. His main fields of interest are sociological and anthropological theories, the history, sociology and philosophy of science and theory of evolution. He published numerous books including Sociology of Science (2010, in Serbian), Evolution and Natural Selection from Anaximander to Darwin (2012, in Serbian, with A. Kišjuhas) and Revolutions and Societies: An Introduction to the Theoretical Sociology of Revolutions (2018, in Serbian, with A. Kišjuhas). He authored numerous scientific papers.

\section{REFERENCES}

ALEXANDER, J. C. - COLOMY, P., 1985: Toward Neo-Functionalism. Sociological Theory 3(2): 11-23. DOI: 10.2307/20221

BARKOW, J. H. - COSMIDES, L. - TOOBY, J. (eds.), 1992: The Adapted Mind. Oxford: Oxford University Press.

BAUMEISTER, R. F. - ZHANG, L. - VOHS, K. D., 2004: Gossip as Cultural Learning. Review of General Psychology 8(2): 111-121. DOI: 10.1037/10892680.8.2.111

BEAUREGARD, K. S. - DUNNING, D., 1998: Turning up the Contrast: SelfEnhancement Motives Prompt Egocentric Contrast Effects in Social Judgments. Journal of Personality and Social Psychology 74(3): 606-621. DOI: 10.1037/00223514.74.3.606

BERGMANN, J. R., 1993: Discreet Indiscretions: The Social Organization of Gossip. New York: Aldine de Gruyter. DOI: 10.1177/017084069501600417

BESNIER, N., 2009: Gossip and the Everyday Production of Politics. Honolulu: University of Hawaii Press. DOI: 10.1353/cp.2011.0012

BISCHOPING, K., 1993: Gender Differences in Conversation Topics, 1922 - 1990. Sex Roles 28(1/2): 1-18. DOI: 10.1007/BF00289744

BLAU, P. M., 1964/1986: Exchange and Power in Social Life. New Brunswick and London: Transaction Publishers. DOI: 10.4324/9780203792643

BLOOM, P., 2004: Postscript to the Special Issue on Gossip. Review of General Psychology 8(2): 138-140. DOI: 10.1037/1089-2680.8.2.138 
BLUMER, H., 1969: Symbolic Interactionism: Perspective and Method. Berkeley: University of California Press. DOI: 10.1177/205684601561

BOYER, P., 2001: Religion Explained: The Evolutionary Origins of Religious Thought. New York: Basic Books. DOI: 10.1207/s15327582ijpr1401_7

BROWN, D. E., 1991: Human Universals. New York: McGraw-Hill.

CHUA, S. V. - DE LA CERNA UY, K. J., 2014: The Psychological Anatomy of Gossip. American Journal of Management 14(3): 64-69. DOI: 10.1080/09589236.2017.1411789

CLANTON, G., 1996: A Sociology of Jealousy. International Journal of Sociology and Social Policy 16(9-10): 171-189. DOI: 10.1177/1754073918795257

COLEMAN, J. S., 1990: Foundations of Social Theory. Cambridge and London: Belknap Press of Harvard University Press.

COLLINS, R., 1975: Conflict Sociology: Toward an Explanatory Science. New York: Academic Press.

COLLINS, R., 1986: Is 1980s Sociology in the Doldrums? The American Journal of Sociology 91(6): 1336-1355. DOI: $10.1086 / 228424$

COMTE, A., 1830-42/1896: The Positive Philosophy of Auguste Comte, 1-3. Freely translated and condensed by Harriet Martineau. London: George Bell \& Sons.

COOK, K. S. - EMERSON, R. M., 1978: Power, Equity and Commitment in Exchange Networks. American Sociological Review 43(5): pp. 721-739. DOI: $10.2307 / 2094546$

COSER, L. A., 1956: The Functions of Social Conflict. London: Routledge. DOI: 10.1177/002200276100500401

COUPLAND, J., 2003: Small Talk: Social Functions. Research on Language and Social Interaction 36(1): pp. 1-6. DOI: 10.1207/S15327973RLSI3601_1

DREW, P. - HERITAGE, J. (eds), 2006: Conversation Analysis. 4 vols. Thousand Oaks: Sage. DOI: 10.4135/9781849208895

DUNBAR, R. I. M. - DUNCAN, N. D. C. - MARRIOTT, A., 1997: Human Conversational Behavior. Human Nature 8(3): pp. 231-246. DOI: 10.1007/BF02912493.

DUNBAR, R. I. M., 1996: Grooming, Gossip and the Evolution of Language. Cambridge, MA: Harvard University Press.

DUNBAR, R. I. M., 2004: Gossip in Evolutionary Perspective. Review of General Psychology 8(2): pp. 100-110. DOI: 10.1037/1089-2680.8.2.100

DURKHEIM, E., 1895/1982: The Rules of Sociological Method. New York: The Free Press. DOI: $10.2307 / 1389262$

DURKHEIM, E., 1912/1915: The Elementary Forms of the Religious Life: A Study in Religious Sociology. Glencoe: The Free Press.

ECKBERG, D. L. - HILL, L. Jr., 1979: The Paradigm Concept and Sociology: A Critical Review. American Sociological Review 44(6): pp. 925-937. DOI: $10.2307 / 2094717$.

ECKHAUS, E. - BEN-HADOR, B., 2017: Gossip and Gender Differences: A Content Analysis Approach. Journal od Gender Studies 28(1): 97-108. DOI: 10.1080/09589236.2017.1411789

Sociológia 52, 2020, No. 6 
EDER, D. - ENKE, J. L., 1991: The Structure of Gossip: Opportunities and Constraints on Collective Expression among Adolescents. American Sociological Review 56(4): 494-508. DOI: 10.2307/2096270

EGGINS, S. - SLADE, D., 1997: Analyzing Casual Conversation. London: Cassell. DOI: $10.4135 / 9781473979697$

EISENSTADT, S. N., 1981: The Schools of Sociology. American Behavioral Scientist 24(3): 329-344. DOI: 10.1177/000276428102400302

EMERSON, R. M., 1962: Power-Dependence Relations. American Sociological Review 27(1): 31-41. DOI: $10.2307 / 2089716$

EMERSON, R. M., 1976: Social Exchange Theory. Annual Review of Sociology 2: 335-362. DOI: 10.1146/annurev.so.02.080176.002003

EMLER, N., 1994: Gossip, Reputation and Social Adaption. In: Good Gossip, R. Goodman and A. Ben-Ze'ev (eds.). pp. 119-140. Lawrence: University of Kansas Press. DOI: 10.1111/j.1559-1816.2012.00956.x

FESTINGER, L., 1954: A Theory of Social Comparison Processes. Human Relations 7(2): 117-140. DOI: 10.1177/001872675400700202

FINE, G. A., 1986: The Social Organization of Adolescent Gossip: The Rhetoric of Moral Evaluation. In: Cook-Gumperz, J., Corsaro, W. and Streeck, J. (eds.), Children's Worlds and Children's Language. Berlin: Mounton: pp. 405-423. DOI: 10.1515/9783110864212.405

FOSTER, E. K., 2004: Research on Gossip: Taxonomy, Methods, and the Future Directions. Review of General Psychology 8(2): 78-99. DOI: 10.1037/10892680.8.2.78

FREIDHEIM, E. A., 1979: An Empirical Comparison of Ritzer's Paradigms and Similar Metatheories: A Research Note. Social Forces 58(1): 59-66. DOI: 10.2307/2094984

FUHRMAN, E. - SNIZEK, W., 1990: Neither Proscience nor Antiscience: Metasociology as Dialogue. Sociological Forum 5(1): 17-36. DOI: 10.1007/BF01115135

GLUCKMAN, M., 1963: Gossip and Scandal. Current Anthropology 4(3): 307-316. DOI: $10.1086 / 200378$

GOFFMAN, E., 1955: On Face-Work. Psychiatry 18(3): 213-231. DOI: 10.1080/00332747.1955.11023008

GOFFMAN, E., 1956: Embarrassment and Social Organization. American Journal of Sociology 62(3): 264-271. DOI: 10.1037/h0076699

GOFFMAN, E., 1959: The Presentation of Self in Everyday Life. New York: Doubleday Anchor Books.

GOFFMAN, E., 1971: Relations in Public: Microstudies of the Public Order. New York: Basic Books.

GOFFMAN, E., 1974: Frame Analysis: An Essay on the Organization of Experience. Boston: Northeastern University Press.

GOODWIN, C. - HERITAGE, J. 1990: Conversation Analysis. Annual Review of Anthropology 19: 283-307. DOI: 10.1146/annurev.an.19.100190.001435 
HAAS, A., 1979: Male and Female Spoken Language Differences: Stereotypes and Evidence. Psychological Bulletin 86(3): 616-626. DOI: 10.1037/00332909.86.3.616

HARPER, D. B. - SYLVESTER, J. - WALCZAK, D., 1980: An Empirical Comparison of Ritzer's Paradigms and Similar Metatheories: Comment on Freidheim. Social Forces 59(2): 513-517. DOI: 10.2307/2578034

HECHTER, M., 1987: Principles of Group Solidarity. Berkeley and Los Angeles: University of California Press. DOI: 10.1177/017084068901000415

HILL, L., Jr. - ECKBERG, D. L., 1981: Clarifying Confusions about Paradigms: A Reply to Ritzer. American Sociological Review 46(2): 248-252. DOI: $10.2307 / 2094984$

HOMANS, G. C., 1961/1974: Social Behavior: Its Elementary Forms - Revised Edition. New York: Harcourt Brace Jovanovich, Inc.

HUTCHBY, I., 1998: Conversation Analysis: Principles, Practices and Applications. Oxford: Polity.

KIPERS, P. S., 1987: Gender and Topic. Language in Society 16(4): 543-557. DOI: 10.1023/A:1024404812972

KUHN, M. H., 1964: Major Trends in Symbolic Interaction Theory in the Past TwentyFive Years. The Sociological Quarterly 5(1): 61-84. DOI: 10.1111/j.15338525.1964.tb02256.x

LANDIS, M. H. - BURTT, H. E., 1924: A Study of Conversations. Journal of Comparative Psychology 4(1): 81-89. DOI:10.1037/h0071502

LIND, P. G. et al., 2007: Spreading Gossip in Social Networks. Physical Review E 76(3): 036117. DOI: 10.1103/PhysRevE.76.036117

LODAHL, J. B. - GORDON, G., 1972: The Structure of Scientific Fields and the Functioning of University Graduate Departments. American Sociological Review 37(1): 57-72. DOI: 10.1007/BF00977340

LUHMANN, N., 1982/1986: Love as Passion: The Codification of Intimacy. Cambridge: Harvard University Press. DOI: 10.1177/0268580914544433a

LUHMANN, N., 1984/1995: Social Systems. Stanford: Stanford University Press. DOI: $10.1177 / 004839319902900402$

MALINOWSKI, B., 1960: A Scientific Theory of Culture and Other Essays. New York: Oxford University Press.

MARTINDALE, D., 1960: The Nature and Types of Sociological Theory. Cambridge, Mass.: Riverside Press. DOI: 10.1177/09526951030163004

MAUSS, M., 1925/1966: The Gift: Forms and Functions of Exchange in Archaic Societies. London: Cohen \& West Ltd.

MCANDREW, F. T., 2008: Can Gossip be Good? Scientific American Mind 19(5): 2633. DOI: 10.1038/scientificamericanmind1008-26

MERTON, R. K., 1968: Social Theory and Social Structure. Enlarged Edition. New York: The Free Press.

MERTON, R. K., 1972: Insiders and Outsiders: A Chapter in the Sociology of Knowledge. The American Journal of Sociology 78(1): 9-47. DOI:10.1086/225294

MOLM, L. D., 1997: Coercive Power in Social Exchange. New York: Cambridge University Press. DOI: 10.1017/CBO9780511626562.011 
MOORE, H. T., 1922: Further Data Concerning Sex Differences. Journal of Abnormal Psychology 17(2): 210-214. DOI: 10.1037/h0063120

ORSTROM, E. - GARDNER, R. - WALKER, J., 1994: Rules, Games and CommonPool Resources. Ann Arbor: University of Michigan Press.

PARSONS, T., 1951: The Social System. New York: The Free Press. DOI: $10.2307 / 202038$

PERRY, N., 1977: A Comparative Analysis of 'Paradigm' Proliferation. The British Journal of Sociology 28(1): 38-50. DOI: 10.2307/589707

RADCLIFFE-BROWN, A. R., 1952: Structure and Function in Primitive Society: Essays and Addresses. Illinois: The Free Press.

RITZER, G., 1975/1980: Sociology: A Multiple Paradigm Science. Revised Edition. Boston: Allyn and Bacon, Inc.

RITZER, G., 1981: Paradigm Analysis in Sociology: Clarifying the Issues. American Sociological Review 46(2): 245-248. DOI: $10.2307 / 2094984$

RITZER, G., 1988: Sociological Metatheory: A Defense of a Subfield by a Delineation of Its Parameters. Sociological Theory 6(2): 187-200. DOI: $10.2307 / 202115$

RITZER, G., 1990: Metatheorizing in Sociology. Sociological Forum 5(1): 3-15. DOI: $10.2307 / 1389512$

ROCK. P., 1979: The Making of Symbolic Interactionism. London and Basingstoke: The Macmillan Press.

ROSNOW, R. L., 1977: Gossip and marketplace psychology. Journal of Communication 27(1): 158-163. https://doi.org/10.1111/j.14602466.1977.tb01811.x

ROSNOW, R. L., 1991: Inside Rumor: A Personal Journey. American Psychologist 46(5): 484-496. DOI: 10.1037/0003-066X.46.5.484

ROSNOW, R. L. - FINE, G. A., 1976: Rumor and Gossip: The Social Psychology of Hearsay. New York: Elsevier.

SCHACHTER, S., 1959: The Psychology of Affiliation: Experimental Studies of the Sources of Gregariousness. Stanford, CA: Stanford University Press.

SCHEFF, T. J., 2000: Shame and the Social Bond: A Sociological Theory. Sociological Theory 18(1): 84-99. DOI: 10.1111/0735-2751.00089

SEIDMAN, S., 1986: Is There Theoretical Growth in Sociology?: Comment on Wagner and Berger. The American Journal of Sociology 92(1): 164-168. DOI: $10.1086 / 228467$

SIMMEL, G., 1950: The Sociology of Georg Simmel. (Edited by K. H. Wolf). New York: The Free Press.

SMITH, A., 1759/2002: The Theory of Moral Sentiments. (Edited by K. Haakonssen). Cambridge: Cambridge University Press. DOI: 10.1017/CBO9780511800153

SOMMERFELD, R. D. - KRAMBECK, H-J. - SEMMANN, D. - MILINSKI, M., 2007: Gossip as an Alternative for Direct Observation in Games of Indirect Reciprocity. Proceedings of the National Academy of Science of the United States of America 104(44): 17435-17440. DOI: 10.1073/pnas.0704598104

SPENCER, H., 1892: Social Statics, Abridged and Revised; Together with The Man Versus the State. London and Edinburgh: Williams and Norgate. 
STIRLING, R. B., 1956: Some Psychological Mechanisms Operative in Gossip. Social Forces 34(3): 262-267. DOI: 10.1177/014616727800400135

STRYKER, S. - BURKE, P. J., 2000: The Past, Present, and Future of an Identity Theory. Social Psychology Quarterly 63(4): 284-297. DOI: 10.2307/2695840

TANNEN, D., 1991: You Just Don't Understand: Women and Men in Conversation. New York: Balantine Books.

THOMAS, W. I. - THOMAS, D. S., 1928: The Child in America: Behavior Problems and Programs. New York: Alfred A. Knopf.

TURNER, J. C., 1975: Social comparison and social identity: Some prospects for intergroup behaviour. European Journal of Social Psychology 5 (1): pp. 5-34. DOI: 10.1002/ejsp.2420050102

TURNER, J. H., 1990: The Misuse and Use of Metatheory. Sociological Forum 5(1): 37-53. DOI: 10.1007/BF01115136.

TURNER, J. H., 1998: The Structure of Sociological Theory. Sixth Edition. Belmont: Wadsworth. DOI: 10.1007/0-387-36274-6

TURNER, R. H., 2002: Role theory. In: J. H. Turner (ed.), Handbook of Sociological Theory. New York, Kluwer Academic/Plenum Publishers: pp. 233-254.

URRY, J., 1973: Thomas S. Kuhn as Sociologist of Knowledge. The British Journal of Sociology 24(4): 462-473. DOI: 10.1177/0038038582016001009

WAGNER, D. G. - BERGER, J., 1985: Do Sociological Theories Grow? The American Journal of Sociology 90(4): 697-728. DOI:10.1086/228142

WAGNER, D. G. - BERGER, J., 1986: Programs, Theory, and Metatheory. The American Journal of Sociology 92(1): 168-182. DOI:10.1111/j.07352751.2005.00247.x

WEBER, M., 1921/1978: Economy and Society: An Outline of Interpretive Sociology. Berkeley: University of California Press. DOI: 10.1093/sf/48.2.269

WERT, S. R. - SALOVEY, P., 2004: A Social Comparison Account of Gossip. Review of General Psychology 8(2): 122-137. DOI: 10.1037/1089-2680.8.2.122

WRIGHT, R., 1994: The Moral Animal: Why We Are the Way We Are. London: Abacus.

YAMAGISHI, T. - COOK, K. S. - WATEBE, M., 1998: Uncertainty, Trust, and Commitment Formation in the United States and Japan. The American Journal of Sociology 104(1): 165-194. DOI: 10.1086/210005 